Natural Hazards and Earth System Sciences (2002) 2: 3-14

(C) European Geophysical Society 2002

\title{
Impact of mapping errors on the reliability of landslide hazard maps
}

\author{
F. Ardizzone ${ }^{1}$, M. Cardinali ${ }^{1}$, A. Carrara ${ }^{2}$, F. Guzzetti ${ }^{1}$, and P. Reichenbach ${ }^{1}$ \\ ${ }^{1}$ CNR-IRPI, Via della Madonna Alta 126, I-06128 Perugia, Italy \\ ${ }^{2}$ CNR-CSITE, Viale Risorgimento 2, I-40136 Bologna, Italy
}

Received: 1 November 2001 - Accepted: 3 December 2001

\begin{abstract}
Identification and mapping of landslide deposits are an intrinsically difficult and subjective operation that requires a great effort to minimise the inherent uncertainty. For the Staffora Basin, which extends for almost $300 \mathrm{~km}^{2}$ in the northern Apennines, three landslide inventory maps were independently produced by three groups of geomorphologists. In comparing each map with the others, large positional discrepancies arise (in the range of 55-65\%). When all three maps are overlain, the locational mismatch of landslide deposit polygons increases to over $80 \%$.

To assess the impact of these errors on predictive models of landslide hazard, for the study area discriminant models were built up from the same set of geologicalgeomorphological factors as predictors, and the occurrence of landslide deposits within each terrain-unit, derived from each inventory map, as dependent variable. The comparison of these models demonstrates that statistical modelling greatly minimises the impact of input data errors which remain, however, a major limitation on the reliability of landslide hazard maps.
\end{abstract}

\section{Introduction}

During the past two decades, investigators have highlighted the inherent errors and uncertainties related to the identification and mapping of landslide deposits through geomorphological techniques (Varnes, 1984; Hansen, 1984; Carrara et al., 1992; Van Westen, 1993; Cruden and Varnes, 1994). Well-trained investigators are capable of detecting and mapping many or most landslides occurring in an area by applying aerial photo-interpretation techniques and systematic field checks (Brabb, 1984; Carrara et al., 1992; Hutchinson, 1995). However, old dormant landslide deposits, landslides intensively modified by farming activity or covered by dense vegetation, cannot be easily identified and correctly mapped.

Correspondence to: F. Ardizzone

(f.ardizzone@ irpi.pg.cnr.it)
All of this introduces a factor of uncertainty that cannot be readily evaluated and explicitly incorporated in the subsequent phases of assessing the hazard and risk affecting human activities.

Such uncertainty largely depends on the skill and experience of the surveyor, and on other factors such as the quality and scale of the available aerial photographs and of the base topographic maps, the typology of the landslide phenomena, and the environmental context.

In this paper, first, three landslide inventory maps, which were independently produced by three groups of geomorphologists, are quantitatively compared, highlighting their positional similarities and discrepancies. Second, two landslide predictive models, which were obtained using the same set of geological-geomorphological factors as predictors, and the occurrence of landslide deposits derived from each inventory map, are compared and discussed. Lastly, the impact of such landslide map and model mismatches on land and urban planning are examined.

\section{Data collection}

The Staffora Basin (Fig. 1), which extends for almost $300 \mathrm{~km}^{2}$ in the northern Apennines (Lombardia Region), has a complex geological-structural setting resulting from the overthrusting of different tectonic units made up of highly fracturated, clay-rich, terrigenous terranes. Such a structurallithological setting, along with a geomorphological environment featured by steep slopes, dissected by a dense, actively eroding, stream network, has led to widespread slope-failures ranging in type and volume from large rotational/translational slides to deep/shallow flow phenomena. Most importantly, many of the landslides are old or very old phenomena that at present are partly dormant whose features appear concealed by either intensive farming activity or thick forest. Since all of this makes the identification and mapping of the landslides difficult and rather subjective, the study area appears ideal for evaluating the errors and discrepancies re- 
Table 1. Summary table of the positional mismatch between the three landslide inventories carried out in the Staffora Basin by the Milano, Perugia and Pavia teams

\begin{tabular}{lcccc}
\hline & Unstable area & & Positional mismatch between maps & $\begin{array}{c}\text { Positional mismatch } \\
\text { among all maps }\end{array}$ \\
\hline & & Milano map & Perugia map & Pavia map \\
\hline Milano map & $19.3 \%$ & $*$ & $57.6 \%$ & $67.7 \%$ \\
Perugia map & $23.7 \%$ & - & $*$ & $67.2 \%$ \\
Pavia map & $16.3 \%$ & - & - & $*$ \\
All maps & & & & $80.0 \%$ \\
\hline
\end{tabular}

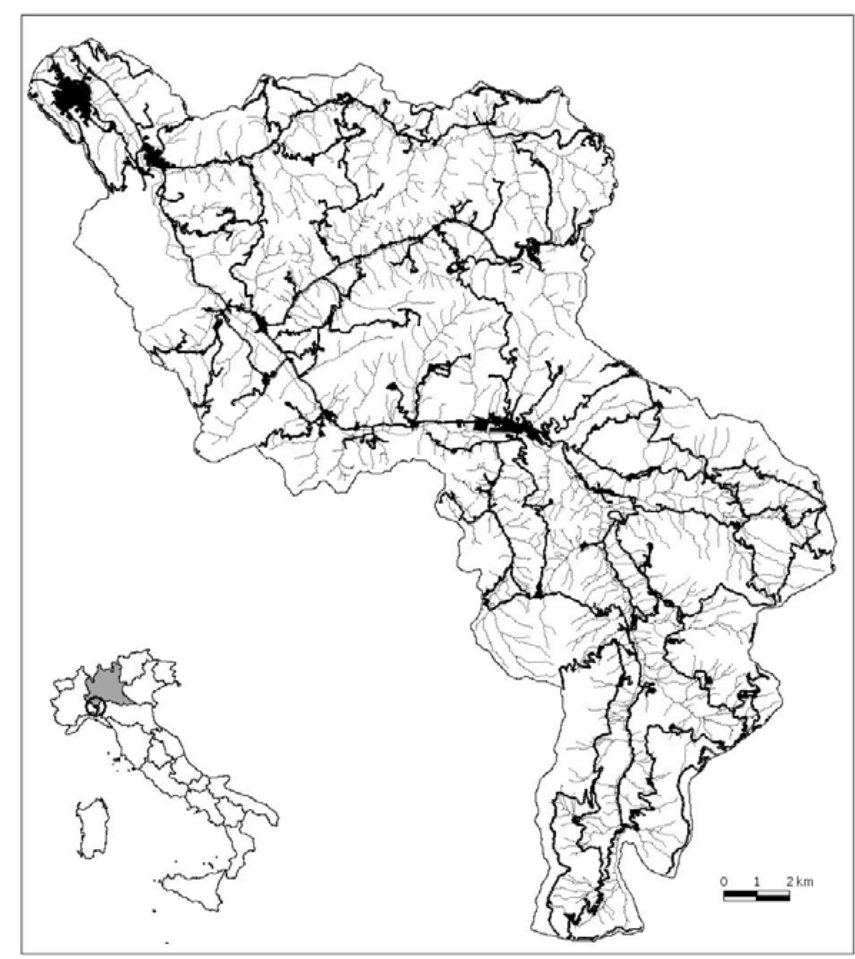

Fig. 1. Staffora Basin. Location of the study area. Thick dark lines and black polygons indicate road network and villages. Grey lines indicate stream network.

sulting from the mapping operations carried out by different geomorphologists.

As part of two different research projects aimed at assessing landslide hazard in the Lombardia Region (Antonini et al., 2000), three landslide inventory maps for the Staffora Basin were independently produced by three groups of geomorphologists from the University of Milano (Department of Geological Sciences and Geotechnology, University of Milano-Bicocca), the Italian National Research Council (CNR-IRPI, Perugia), and the Soil Conservation Office of the Province of Pavia, respectively.

To map the landslides, the investigators from the University of Milan used colour, 1:15000 in scale, aerial photographs flown in 1981-1982; the laboratory work was in- tegrated and tested by numerous field checks. The CNRIRPI (Perugia) team used black-and-white, 1:25000 in scale, aerial photos flown in 1994. Very limited field checks were used to validate the photo-interpretation. Lastly, the Province of Pavia investigators used 1:20000 in scale aerial photographs and an unknown number of field surveys.

All maps were carefully digitised and to each landslide deposit a list of attributes was assigned containing information on the type of movement, estimated relative age (very old, old, recent), degree of activity (dormant and active) and degree of certainty (low, intermediate, high certainty), in the identification of the failed mass. Since these attributes were assigned to the landslides using somewhat different criteria, the comparison between the three inventories was mainly confined to their positional (or locational) matching.

\section{Data analysis}

\subsection{Comparison of landslide inventory maps}

Since all data were stored into a GIS (ArcGis by ESRI), it was readily possible to compare landslide polygons derived from the three inventories through the use of the "map overlay" functions, now days available in any commercial GIS.

First, the comparison was performed pairwise (Figs. 2, 3 and 4) then it was extended to all three maps (Fig. 5). By applying simple operations from set theory, the positional mismatch (PM) was calculated as follows (see Carrara et al., 1992):

$\mathrm{PM}=\left[\left({ }^{\prime} \mathrm{A}\right.\right.$ ' $\cup$ 'B' - 'A' $\cap$ 'B') / 'A' $\cup$ 'B'] $\times 100$

where:

'A', 'B' Landslide inventory maps

'A' $\cup$ 'B' Spatial union of landslide maps

'A' $\cap$ 'B' Spatial intersection of landslide maps

The map resulting from the union operation ('A' $U$ ' $B$ ') incorporates all the polygons classified as landslide deposits by either the A inventory or the B inventory. While the map obtained by the intersection operation ('A' $\cap$ ' $B$ ') includes only the unstable area common to the two inventories. Clearly, the index will approach $0 \%$ in the ideal case that inventory maps 


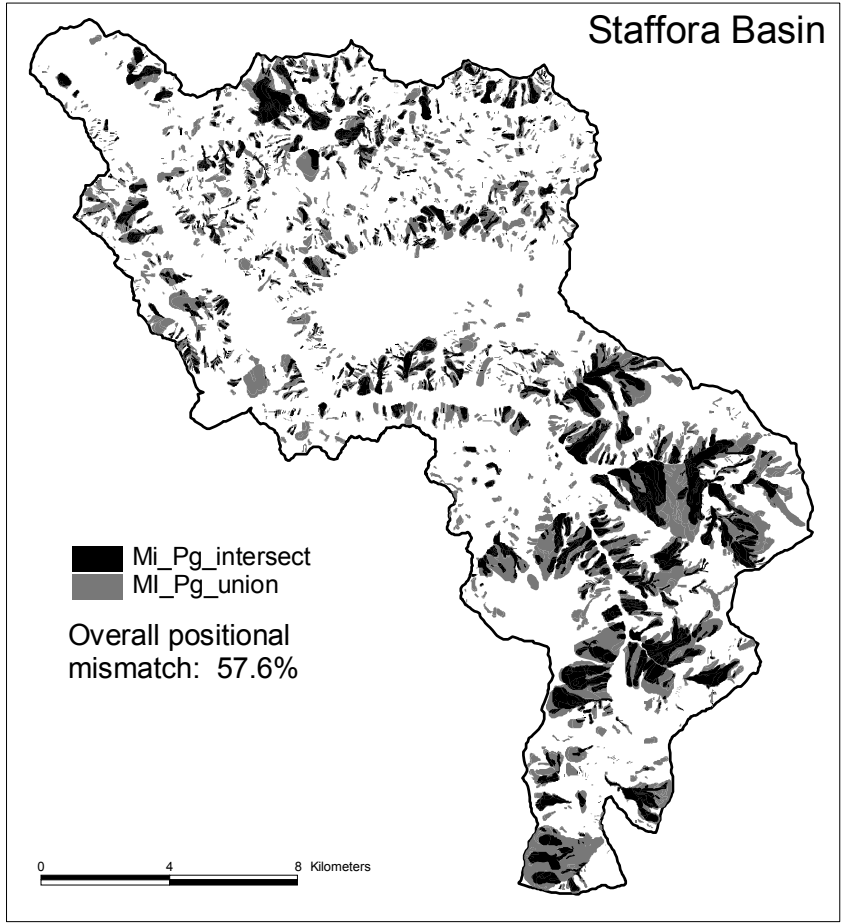

Fig. 2. Comparison of landslide inventory maps produced by the University of Milano (Mi) and the CNR-IRPI in Perugia (Pg) research teams. Total area classified as unstable by either Milano or Perugia (union) is in grey. Unstable area common to the two inventories (intersection) is in black.

match exactly, and will assume large values, in the range of $50-70 \%$, for the more realistic circumstance that maps differ.

Therefore, the index of disagreement between landslide maps represents the total error and uncertainty associated with landslide identification, interpretation, classification, topographic location, and aerial photograph-to-map data transfer and data digitizing.

The comparison of landslide maps produced by different investigators indicated that the positional mismatch due to factors resulting from photointerpreter skill or subjectivity differences, amounts to less than 10\% (Carrara et al., 1992). Hence, to estimate the importance of the ability and experience of the surveyor in map disagreement, the figures reported in Table 1 should be approximately reduced of this value.

From the values summarised in Table 1, it is apparent that the overall percentage of unstable area of the Staffora Basin largely differs among the three inventories. Likewise, the disagreement between each map approaches $68 \%$, while the mismatch among the three data sets increases to $80 \%$. These large discrepancies can be accounted for by various factors.

First, the Milano and Perugia investigators used different aerial photographs, namely colour, 1:15000, photographs flown in 1981-1982 vs. black-and-white, 1:25000, photographs flown in 1994. The 1981-1982 set of photographs were taken shortly after an event of heavy rains that gen-

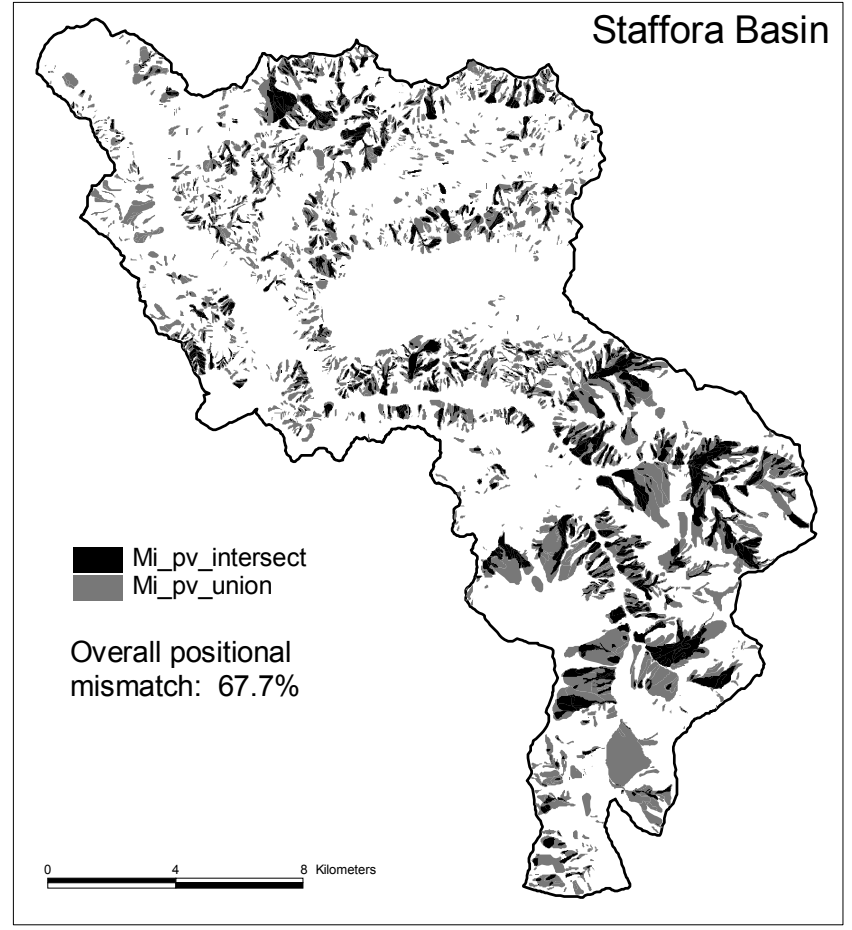

Fig. 3. Comparison of landslide inventory maps produced by the University of Milano (Mi) and the Province of Pavia (Pv) research teams. Total area classified as unstable by either Milano or Pavia (union) is in grey. Unstable area common to the two inventories (intersection) is in black.

erated widespread surficial flow phenomena on cultivated slopes. Hence, these failures were readily mapped by the Milano geomorphologists. At the time the second set of photographs were flown (1994), most of these deposits were cancelled out by the farming activity and could not be detected by the Perugia geomorphologists.

Second, the Milano teams integrated the laboratory work with systematic field checks, while the Perugia team spent just few days visiting the study area.

Despite of this, the mismatch between Milano and Perugia inventory maps is smaller $(57.6 \%)$ than that regarding both the Perugia-Pavia (67.2\%) and the Milano-Pavia $(67.7 \%)$ landslide maps where either the photographs or the amount of field work were comparable. Hence, all of this leads to idea that the major cause of the positional mismatch is mainly linked to the way the investigator identifies, infers and interprets the geomorphological expression of landslide deposits.

\subsection{Positional mismatch and applicability of landslide maps}

The disagreement index provides a synthetic estimate of how the landslide deposits mapped by the three research teams overlie each other throughout the basin, including both populated zones and mountain areas that today are totally abandoned. Hence, the question may be to which extent the mis- 


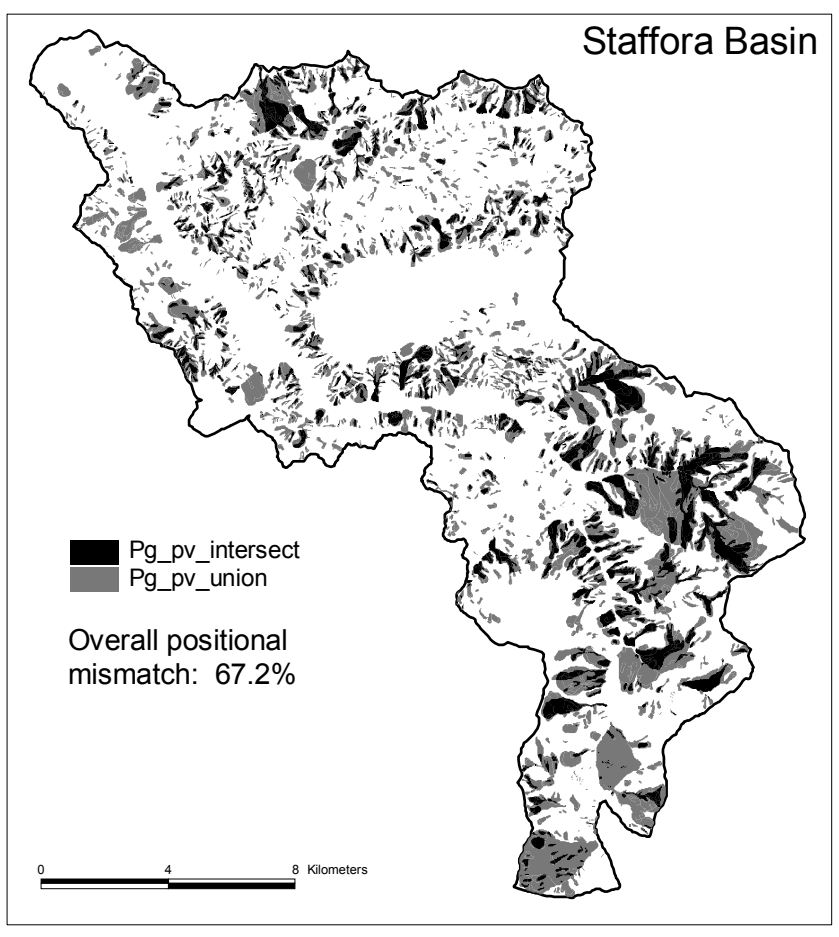

Fig. 4. Comparison of landslide inventory maps produced by the CNR-IRPI in Perugia (Pg) and the Province of Pavia (Pv) research teams. Total area classified as unstable by either Perugia or Pavia (union) is in grey. Unstable area common to the two inventories (intersection) is in black.

Table 2. Summary table of the positional mismatch between the three landslide inventories, carried out in the Staffora Basin by the Milano, Perugia and Pavia research teams, confined to the slopes located within a distance less than $100 \mathrm{~m}$ from villages and roads

\begin{tabular}{lccc}
\hline & \multicolumn{3}{c}{ Positional mismatch between maps } \\
\hline & Milano map & Perugia map & Pavia map \\
\hline Milano map & $*$ & $58.9 \%$ & $67.8 \%$ \\
Perugia map & - & $*$ & $67.4 \%$ \\
\hline
\end{tabular}

match affects the reliability and applicability of the inventories in the urbanised parts of the basin where landslide control and mitigation are most important. Indeed, it may be assumed that the inventory maps are more accurate in the areas near villages or roads where historical information is available, field checking easier and the care of the surveyor greater.

The outcomes of a visual inspection of the relations between landslide mapping and man-made structures are exemplified in Fig. 6 where three small villages (A, B and C) are located. In the Milano and Perugia landslide maps the eastern portion of village A appears affected by mass movement, while in the Pavia map slope failures occur also in the western section of the urban area.

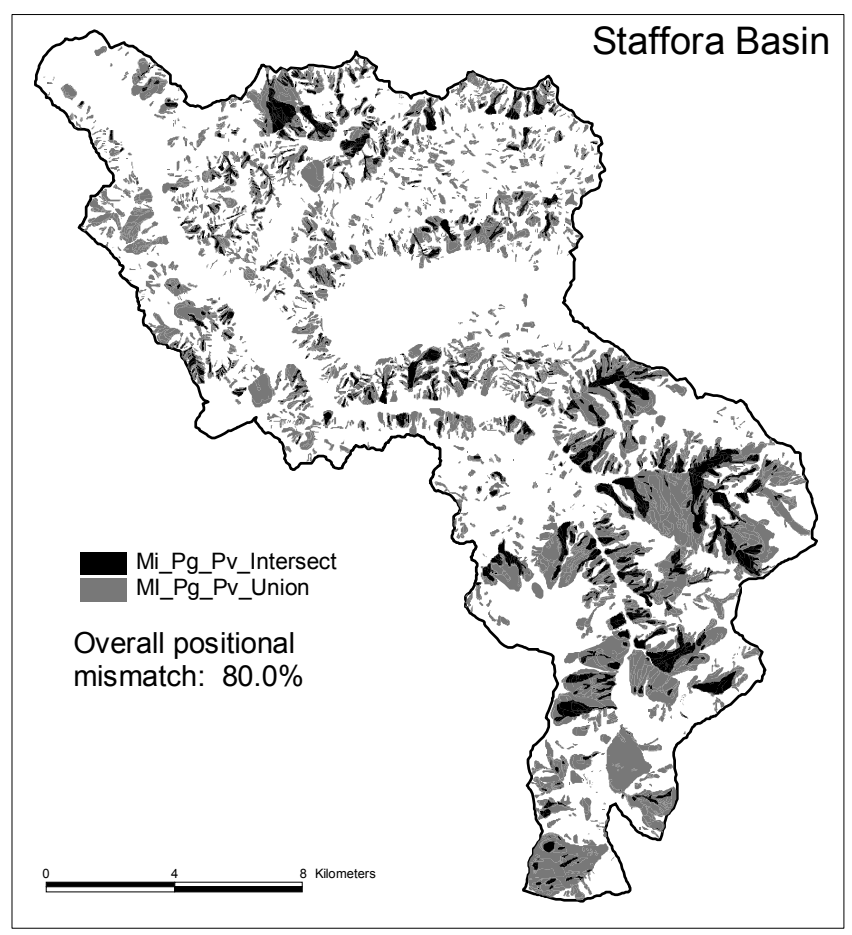

Fig. 5. Comparison of landslide inventory maps produced by the three research teams. Total area classified as unstable by either Milano or Perugia or Pavia (union) is in grey. Unstable area common to the three inventories (intersection) is in black.

In the Milano inventory village B is totally free of landsliding; conversely, the Perugia and Pavia maps both classify the area as severely affected by mass movements that however differ from each other in location and typology (rotational slide vs. slides and flows). Lastly, all three inventories fully agree in placing village $\mathrm{C}$ at the toe of a very large rotational landslide whose morphological expression does not lead to equivocal interpretations.

As a result, the instability conditions of two villages were interpreted in a rather different way, while the third one located on a landslide deposit was accurately identified by the three teams.

As far as the road network is concerned, in all the three maps nearly the same tracts of roads lie on unstable slopes with the higher proportion in the Perugia inventory map and the smaller percentage in the Milano one.

By expanding the visual comparison to the slopes of the countryside, it is apparent that the three maps report landslide deposits in a rather different way, as quantitatively assessed by the mismatch percentages listed in Table 1 .

In order to evaluate the landslide map errors in areas where villages and life-lines occur in a more systematic way, it would be necessary to identify all slopes whose morphological evolution can affect dwellings or other man-made structures: a rather time consuming and complex operation.

A simple, approximate alternative consists in the generation of a buffer corridor of a given width along roads and 


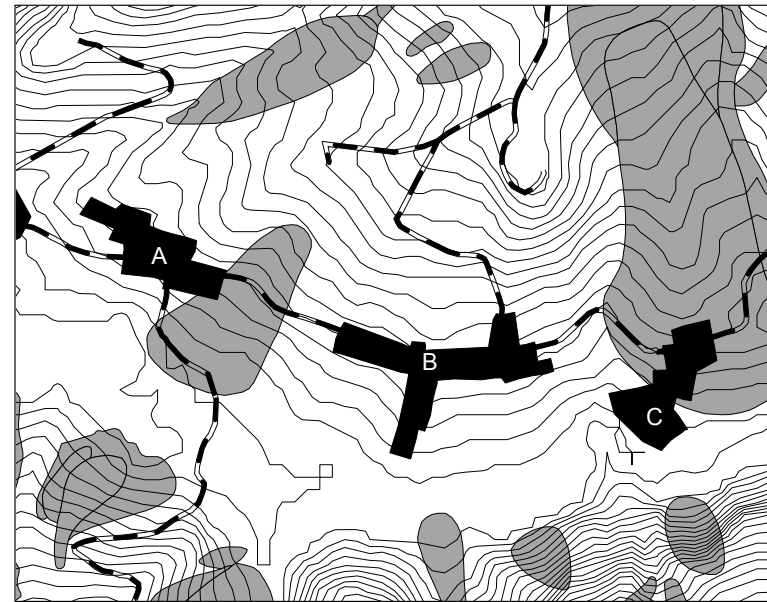

Milano landslide inventory

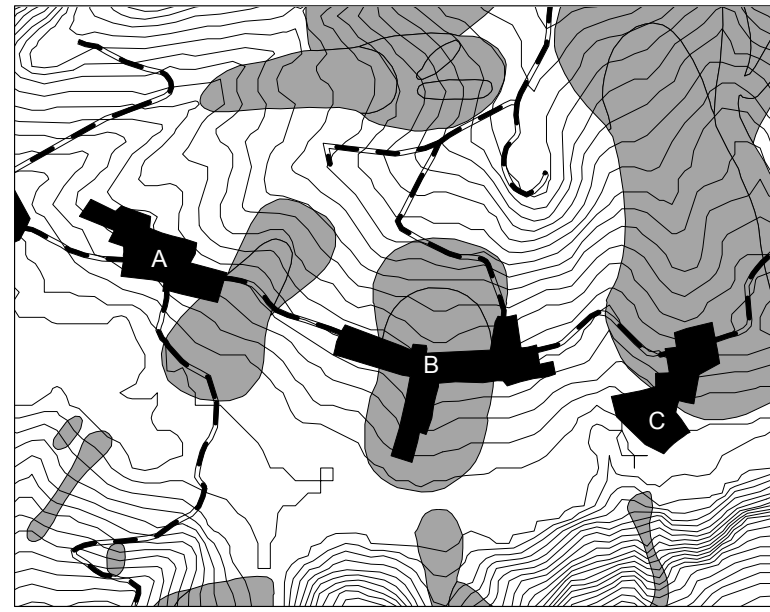

Perugia landslide inventory
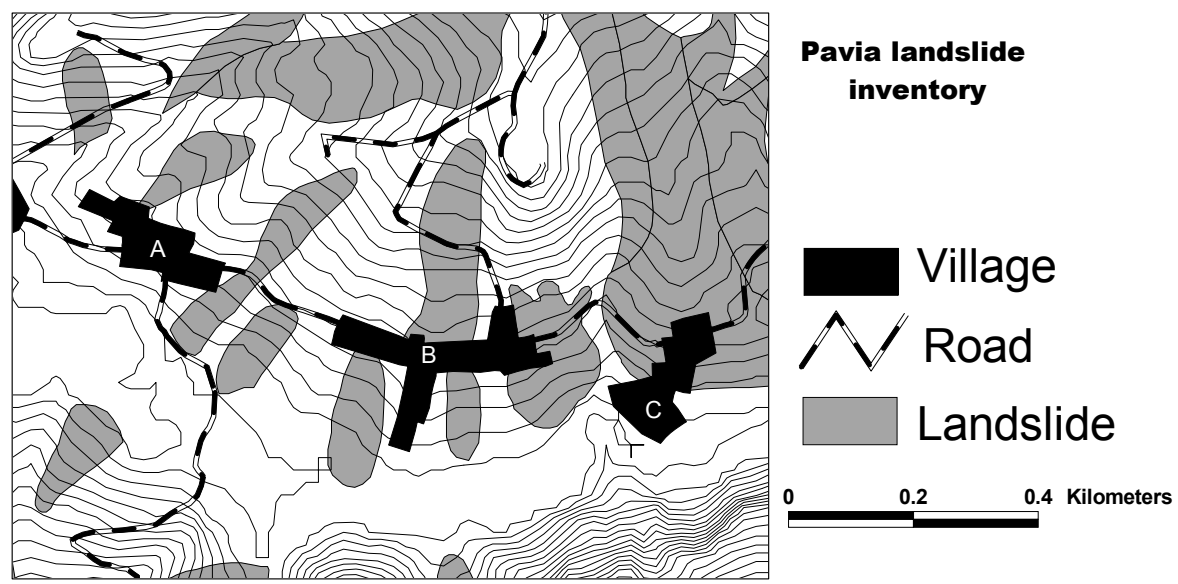

Fig. 6. Comparison of the three landslide inventory maps in a portion of the basin area where three small villages (A, B and C) are located.

around urban areas. Time constraints forced this second approach and a buffer, $100 \mathrm{~m}$ wide, along the road network and around villages and towns was generated. The buffer map was then used to produce a new set of inventory maps where only landslide deposits located within the buffer area were preserved (Fig. 7). Finally, the previous analysis was repeated on this new data set whose results are displayed and summarized in Table 2.
The positional mismatch, as expressed by the disagreement index, between the Perugia, Milano and Pavia inventories is very close to that for the whole basin area. Hence, it is apparent that the landslides located near at or far away from man-made structures were mapped with the same care and attention. If this demonstrates that the research teams worked in a consistent and systematic way, the impact of the inherent uncertainty in mapping landslide deposits appears a 


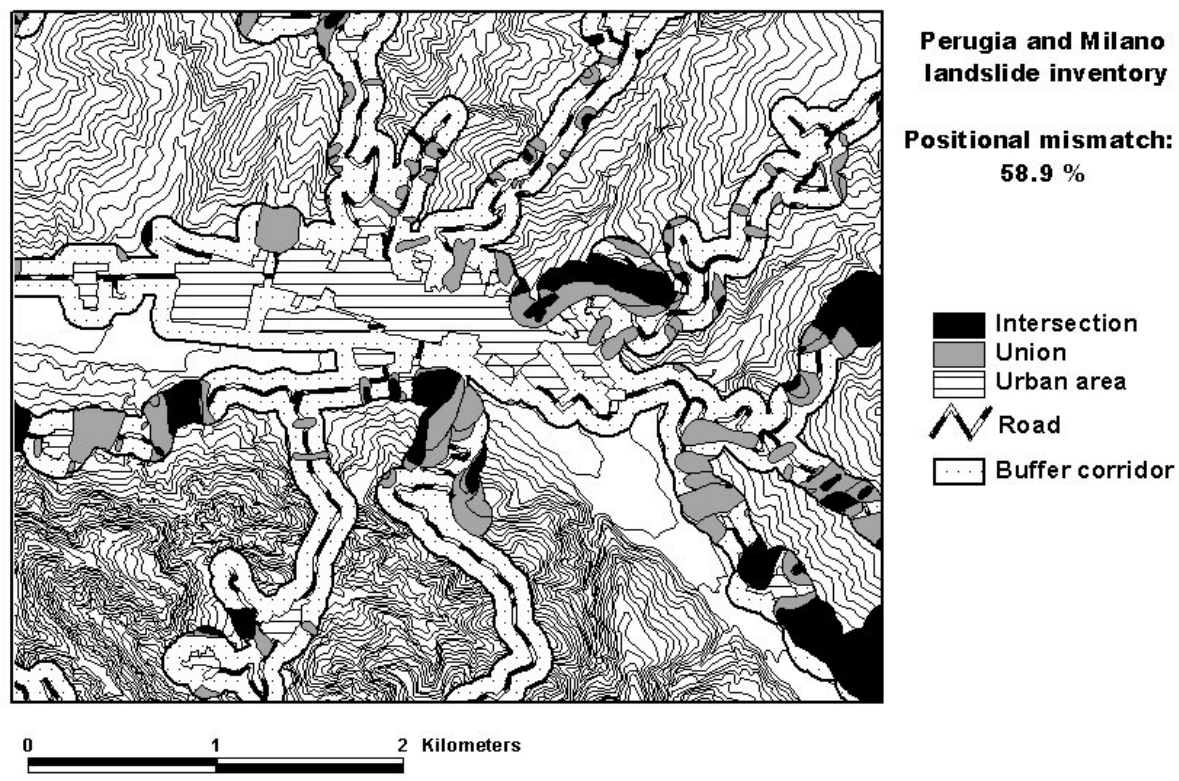

Fig. 7. Portion of the Staffora Basin. Comparison of the Milano and Perugia inventory maps confined to the slopes located within a distance of less than $100 \mathrm{~m}$ from roads and villages.

Table 3. Summary table of disagreement between landslide density maps derived from the inventories carried out in the Staffora Basin by the Milano, Perugia and Pavia research teams

\begin{tabular}{cccc}
\hline \multicolumn{4}{c}{ Disagreement between terrain units } \\
\hline & $\begin{array}{c}\text { Milano } \\
\text { density map }\end{array}$ & $\begin{array}{c}\text { Perugia } \\
\text { density map }\end{array}$ & $\begin{array}{c}\text { Pavia } \\
\text { density map }\end{array}$ \\
\hline $\begin{array}{c}\text { Milano } \\
\text { density map }\end{array}$ & $*$ & $21.2 \%$ & $23.8 \%$ \\
$\begin{array}{c}\text { Perugia } \\
\text { density map }\end{array}$ & - & $*$ & $25.1 \%$ \\
\hline
\end{tabular}

major drawback for the applicability of this type of information in land and urban planning.

All of this points out the need to look for an alternative way to transfer hazard information to technicians and local administrators when they have to make decision on where and how restrictions shall be placed on the use of the land.

\subsection{Comparison of landslide density maps}

The first attempt to minimise the mismatch between the three inventories involved conversion of the landslide maps into density maps. The technique, which has been frequently applied (Brabb et al., 1972; Campbell, 1973; DeGraff, 1985; Wright and Nilsen, 1974; Guzzetti et al., 2000), implies the calculation of the percentage of landslide area within a given, pre-defined terrain unit. Traditionally, the mapping unit is a grid cell and density is determined counting the percentage of landslide area within a moving window of pre-defined size and shape.

A well-known drawback of these density maps is that these maps lay on the false assumption that landslide occurrence is a spatially continuous variable that can be interpolated without considering the relations existing between landslide occurrence and the local morphological and geological settings.

To overcome this conceptual limitation, a feasible alternative consists in the selection of a proper mapping unit, different from grid-cells. Among all the mapping units proposed in the literature (Carrara et al., 1995; Guzzetti et al., 1999), slope-units appear to be, at least conceptually, particularly suited (Carrara et al., 1991, 1995). Slope-units partition the territory into domains comprised between drainage and divide lines. They can be automatically derived from DTMs and correspond, more or less accurately depending on the quality and resolution of the DTM, to actual slopes, where landsliding takes place. Being bounded by morphological boundaries that, most commonly, constrain the occurrence and development of landslides (i.e. divides and rivers) they avoid the problem of forecasting high densities of landslides in areas that were mapped as essentially landslide free, but that are spatially close to known landslides.

Consequently, the basin area was automatically partitioned into main slope-units (i.e. right/left sides of elementary sub-basins) through a specifically-designed software module which, starting from a high-quality DTM, generates fully connected and complementary drainage and divide networks, and a wide spectrum of morphometric parameters of channels and slopes (Carrara, 1988; Carrara et al., 1995). Main slope units were then subdivided according to the main rock types cropping out in the basin. In this way, the study basin was partitioned into 2245 terrain-units.

By overlaying this terrain-units map on the three landslide 


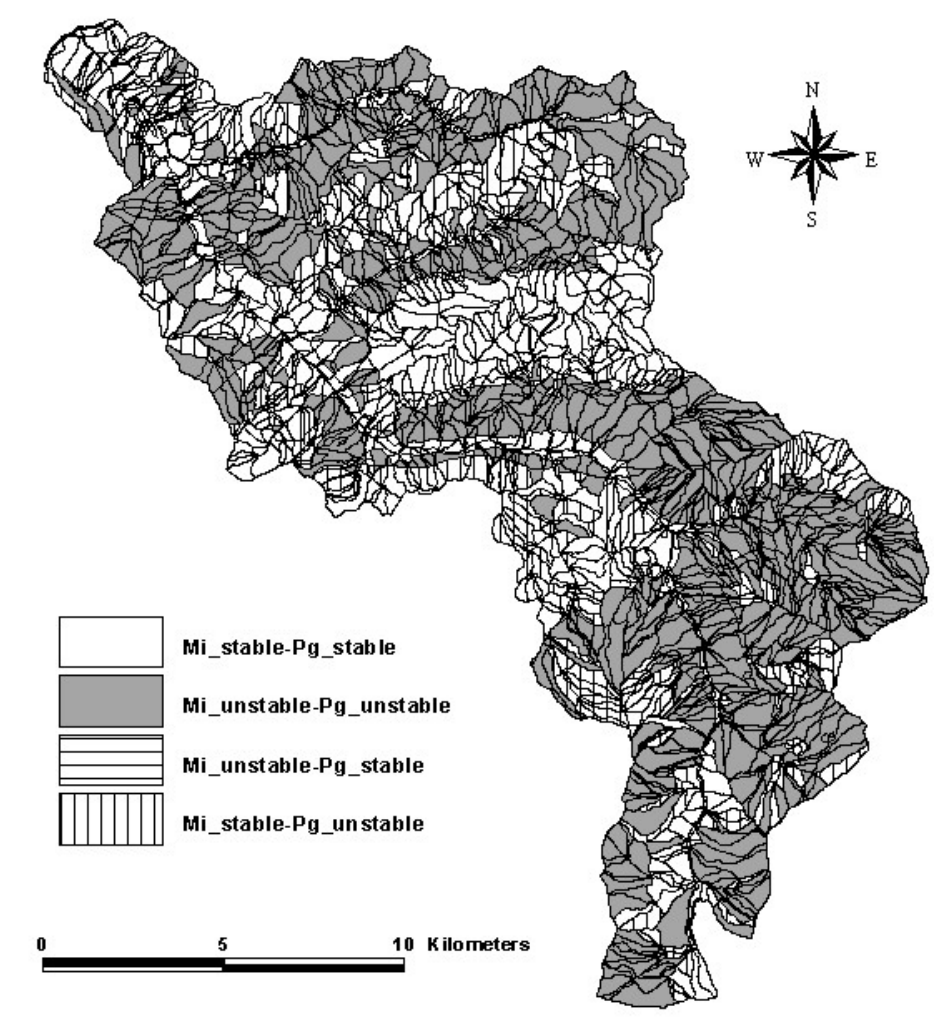

Fig. 8. Comparison of the landslide hazard maps derived from discriminant models for the Staffora Basin. Predicting variables are a set of geological-geomorphological factors of the basin (Tables 4 and 5) and predicted variables are the landslide inventory maps from either the Milano (Mi) or the Perugia $(\mathrm{Pg})$ research teams.

inventories, the percentage of failed mass of each terrain-unit was calculated and grouped into two classes: units with a landslide density greater or less than 5\%. This class limit was simply selected by estimating the maximum locational error due to the transfer of landslide polygons from the aerial photographs to the base topographic maps.

The comparison of these reclassified density maps showed that their differences range from 21.2 to $25.1 \%$, nearly one third of the positional mismatches observed when the original inventory maps were compared (Table 3 ).

This gain in agreement among different sources of landslide data has a severe cost in terms of loss of spatial resolution, which should be compensated by introducing into the system new information derived from other data. This can be accomplished by applying multivariate models.

\subsection{Comparison of landslide multivariate models}

The next phase of the investigation consisted in the development of multivariate models of landslide hazard for the Staffora Basin. The rationale and implementation of a statistical hazard model are described in detail in previous papers (Carrara et al., 1995, 1999; Guzzetti et al., 1999). Hence, here it will suffice to mention that a large (over 50 variables) set of geological-morphological factors were acquired and used as predictors of landslide hazard and the presence/absence of landslide deposits within each terrain-unit as predicted (dependent) variable of a statistical multivariate procedure (in the present work: discriminant analysis). The occurrence of landslide deposits was obtained from the inventory maps produced by research teams with the exclusion of the Pavia map because for this inventory the needed information on landslide characteristics could not be acquired.

In the model predicting the Milano landslides, 40 variables were selected by a stepwise procedure (Table 4a). Among the lithological variables, those with the largest standardised discriminant function coefficients are: the presence within the terrain unit of alluvional deposits (ALLUVIO), massive sandstones (AR_BIS) and calcareous marls (MR_AN_LO). Of the land use/land cover variables the most relevant are: the presence of tilled fields (SEM), denudated surfaces (INC), pastures (PRA) and vegetation less areas (ALV). Among the morphometric variables, terrain-unit mean slope angle (SLO_ANG) and its square (SLO_ANG2) have large coefficients witnessing a curvilinear relation between steepness and landslide frequency, namely, landsliding first increases with slope angle up to a threshold value above which the relation does not hold true any more (Carrara et al., 1995). Terrain-unit area (SLO_AR) and local relief (ELV_STD) have 


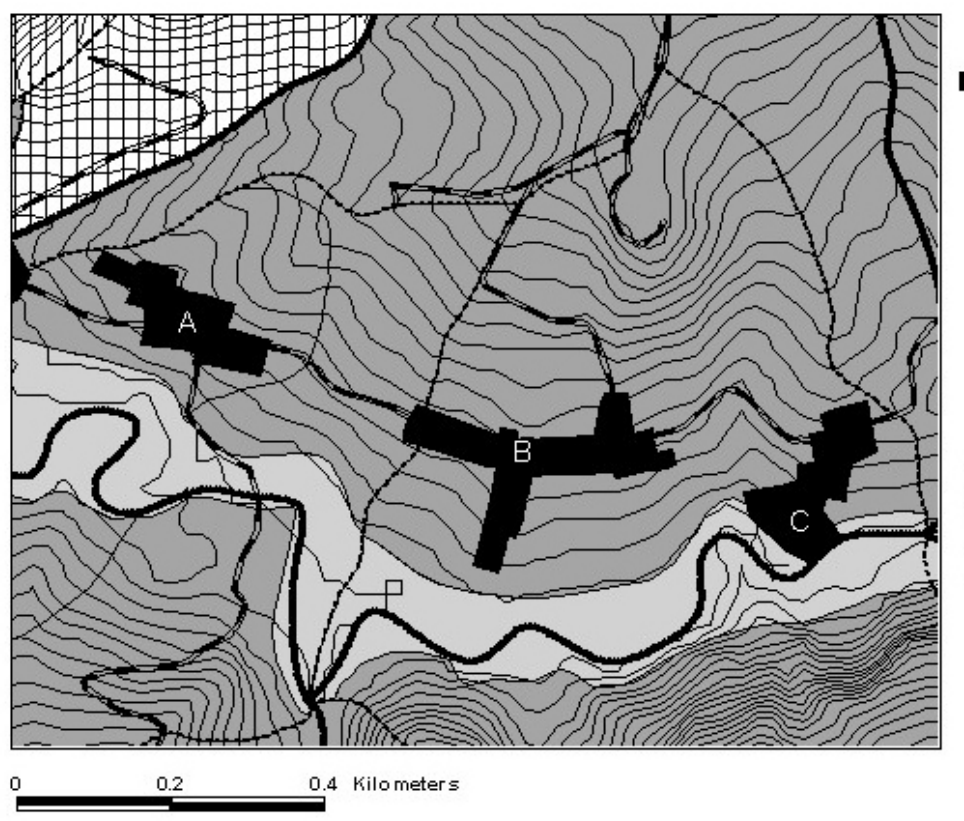

\section{Comparison of Milano and Perugia models}

Fig. 9. Detail of Fig. 8 displaying the portion of the Staffora Basin shown in Fig. 6.

also large coefficients.

Since the discriminant function assumes a negative $(-0.75)$ and a positive $(0.67)$ value at the centroids (mean values in a multidimensional space) of the groups of unstable and stable terrain-units, predictors with negative and positive coefficients are in favour (i.e. factor SEM $=-0.557$ ) and against (i.e. factor AR BIS $=0.314$ ) landslide occurrence, respectively.

Outcomes of the analysis indicate that such a mix of environmental factors is capable of predicting, with a reliability of the $77 \%$, which terrain units are affected by or are free of landslide deposits (Table 4b).

In the model predicting the Perugia landslides, 36 variables were selected by a stepwise procedure (Table 5a). Among the lithological and structural variables, those with the largest standardised discriminant function coefficients are: the presence within the terrain unit of alluvional deposits (ALLUVIO), massive sandstones (AR BIS), calcareous marls (MR_AN_LO) and bedding dipping toward the slope free face (REG). Of the land use/land cover variables the most relevant are: the presence of tilled fields (SEM), denudated surfaces (INC), pastures (PRA) and vegetation less areas (ALV). Among the morphometric variables, terrain-unit mean slope angle (SLO_ANG) and its square (SLO_ANG2) have the largest coefficients. Terrain-unit area (SLO_AR) and slope angle standard deviation (ANG_STD) have also large coefficients. Also in this case, the centroids of the unstable and stable groups have negative $(-0.56)$ and positive (1.00) values, hence the sign of the coefficients has to be interpreted as outlined above.

The results of this second model show that this mix of environmental factors is capable of predicting, with a reliabil- ity of the $78 \%$, which terrain units are affected by or free of landslide deposits (Table 5b).

It is worth noting that in both models nearly the same set of predictors were selected by the stepwise procedure and entered into the discriminant functions, and nearly the same percentage of terrain-units was correctly classified.

At this stage it was readily possible to compare the outcomes of the two hazard models by grouping the model probabilities of landslide occurrence into two classes, namely: terrain-units with a probability greater (unstable) or smaller (stable) than 0.5. The comparison matrix of Table 6 indicates that the overall model disagreement is equal to $15.5 \%$ : namely nearly one forth of the positional mismatch observed when the original inventory maps were confronted (Table 1).

Outcomes of the Milano and Perugia model comparison were also used to produce the map of Fig. 8 where terrain units were grouped into 4 classes of which the first two indicate stable $(37.7 \%)$ and unstable $(46.8 \%)$ conditions predicted by both models, and the last two identify the basin areas where the instability conditions forecast by of the two models are in conflict (summing up to $15 \%$ ).

Lastly, Fig. 9 displays the Milano vs. Perugia hazard models for the portion of the basin area of Fig. 6, where three small villages (A, B and C) are located. Here both models agree in classifying the entire slopes on which the villages are built up as areas susceptible to slope failure.

\section{Conclusions}

Many studies world-wide have demonstrated that traditional geomorphological investigations in the laboratory (aerial-photo interpretation) and in the field (geological- 
Table 4. Staffora Basin. (a) List of the 40 variables selected by a stepwise procedure of the discriminant analysis as best predictors of the occurrence in the terrain-units of landslide deposits derived from the Milano inventory. The most important standardised discriminant function coefficients (SDFC) are in bold. Group centroids are: stable terrain-units $=0.67$; unstable terrain-units $=-0.75$. (b) Classification of stable and unstable terrain-units using landslide deposits as predicted variable

(a)

\begin{tabular}{|c|c|c|}
\hline Variable & Description & SDFC \\
\hline AR_VA_PA & $\%$ of tectonic clayey melange in the terrain-unit & .113 \\
\hline ALB_ZEB & $\%$ of clays, marls and limestones in the terrain-unit & .080 \\
\hline ALLUVIO & $\%$ of recent alluvium deposits in the terrain-unit & .768 \\
\hline AR_BIS & $\%$ of massive sandstones in the terrain-unit & .314 \\
\hline AR_R_M_P & $\%$ of sandstones and marls in the terrain-unit & .047 \\
\hline AT_PA_CA & $\%$ of marly clayey chaotic complex in the terrain-unit & .194 \\
\hline CA_PEN & $\%$ of marls and limestones in the terrain-unit & -.160 \\
\hline DETRITO & $\%$ of detritic deposits in the terrain-unit & -.096 \\
\hline MR_AN_LO & $\%$ of calcareous marls in the terrain-unit & .391 \\
\hline MR_B_R_C & $\%$ of marls and sandstones in the terrain-unit & .198 \\
\hline MR_BOSM & $\%$ of marls in the terrain-unit & .030 \\
\hline MR_P_R_B & $\%$ of clayey marls in the terrain-unit & .127 \\
\hline SACONG & $\%$ of sands and conglomerates in the terrain-unit & .186 \\
\hline INSIDE & $\%$ of area fractured by faulting in the terrain-unit & .030 \\
\hline REG & $\%$ of beds dipping toward the slope free face in the terrain-unit & .122 \\
\hline FRA & $\%$ of beds dipping away the slope free face in the terrain-unit & .100 \\
\hline $\mathrm{CAO}$ & $\%$ of chaotic bedding in the terrain-unit & -.106 \\
\hline TR3 & Terrain-unit facing SW & .158 \\
\hline ALV & $\%$ of vegetation less area in the terrain-unit & -.280 \\
\hline BD & $\%$ of densely forested area in the terrain-unit & .074 \\
\hline INC & $\%$ of denudated area in the terrain-unit & -.269 \\
\hline PRA & $\%$ of pasture area in the terrain-unit & -.300 \\
\hline RIM & $\%$ of reforested area in the terrain-unit & -.031 \\
\hline SEM & $\%$ of tilled area in the terrain-unit & -.557 \\
\hline URB & $\%$ of urbanised area in the terrain-unit & -.101 \\
\hline VIG & $\%$ of vineyard area in the terrain-unit & -.092 \\
\hline MAGN & Channel magnitude & .167 \\
\hline LINK_LEN & Channel length & .102 \\
\hline SLO_ARE & Terrain-unit area & -.259 \\
\hline $\mathrm{R}$ & $\mathrm{I}^{\circ}$ index of terrain-unit micro-relief & .160 \\
\hline ELV_STD & Standard deviation of terrain-unit mean elevation & -.264 \\
\hline SLO_ANG & Mean slope angle & -.310 \\
\hline SLO_ANG2 & Mean slope angle squared & .480 \\
\hline ANG_STD & Standard deviation of slope angle & .177 \\
\hline LINK_ANG & Mean channel angle & .070 \\
\hline LEN_STD & Standard deviation of channel angle & -.073 \\
\hline CONV & Convex slope profile & -.033 \\
\hline COC_COV & Concave-convex slope profile & .051 \\
\hline RET & Rectilinear slope profile & .042 \\
\hline IRR & $\mathrm{II}^{\circ}$ index of terrain-unit micro-relief & .076 \\
\hline
\end{tabular}

(b)

\begin{tabular}{lcc}
\hline Actual groups & Predicted group membership & \\
\hline & Group 1 (stable slopes) & Group 2 (unstable slopes) \\
\hline Group 1 (stable slopes) & $73.9 \%$ & $26.1 \%$ \\
Group 2 (unstable slopes) & $19.5 \%$ & $80.5 \%$ \\
\hline
\end{tabular}

Terrain-units correctly classified: $77.0 \%$

geomorphological survey), are the best tool for identifying and mapping landslide deposits (Dikau et al., 1996). The maps obtained in this way provide valuable information on the spatial distribution and the geomorphological character- 
Table 5. Staffora Basin. (a) List of the 36 variables selected by a stepwise procedure of the discriminant analysis as best predictors of the occurrence in the terrain-units of landslide deposits derived from the Perugia inventory. The most important standardised discriminant function coefficients (SDFC) are in bold. Group centroids are: stable terrain-units $=1.00$; unstable terrain-units $=-0.56$. $(\mathbf{b})$ Classification of stable and unstable terrain-units using the landslide deposits as predicted variable

(a)

\begin{tabular}{|c|c|c|}
\hline Variable & Description & SDFC \\
\hline ALB_ZEB & $\%$ of clays, marls and limestones in the terrain-unit & .030 \\
\hline ALLUVIO & $\%$ of recent alluvium deposits in the terrain-unit & .827 \\
\hline AR_BIS & $\%$ of massive sandstones in the terrain-unit & .441 \\
\hline AT_PA_CA & $\%$ of marly clayey chaotic complex in the terrain-unit & .075 \\
\hline CA_AN_CA & $\%$ of calcareous flysh the terrain-unit & -.114 \\
\hline CA_PEN & $\%$ of marls and limestones in the terrain-unit & -.110 \\
\hline DETRITO & $\%$ of detritic deposits in the terrain-unit & -.113 \\
\hline MR_AN_LO & $\%$ of calcareous marls in the terrain-unit & .210 \\
\hline MR_BOSM & $\%$ of marls in the terrain-unit & .042 \\
\hline MR_P_R_B & $\%$ of clayey marls in the terrain-unit & .115 \\
\hline SACONG & $\%$ of sands and conglomerates in the terrain-unit & .144 \\
\hline REG & $\%$ of beds dipping toward the slope free face in the terrain-unit & .319 \\
\hline FRA & $\%$ of beds dipping away the slope free face in the terrain-unit & .160 \\
\hline $\mathrm{CAO}$ & $\%$ of chaotic bedding in the terrain-unit & .100 \\
\hline TR1 & Terrain-unit facing NE & -.238 \\
\hline TR3 & Terrain-unit facing SW & -.125 \\
\hline ALV & $\%$ of vegetation less area in the terrain-unit & -.236 \\
\hline BMD & $\%$ of forested area in the terrain-unit & -.108 \\
\hline INC & $\%$ of denudated area in the terrain-unit & -.256 \\
\hline PRA & $\%$ of pasture area in the terrain-unit & -.283 \\
\hline RIM & $\%$ of reforested area in the terrain-unit & .031 \\
\hline SEM & $\%$ of plown area in the terrain-unit & -.374 \\
\hline URB & $\%$ of urbanised area in the terrain-unit & -.084 \\
\hline VIG & $\%$ of vineyard area in the terrain-unit & -.032 \\
\hline MAGN & Channel magnitude & .150 \\
\hline SLO_ARE & Terrain-unit area & -.221 \\
\hline $\mathrm{R}$ & $\mathrm{I}^{\circ}$ index of terrain-unit micro-relief & .194 \\
\hline ELV_M & Mean elevation of the terrain-unit & .078 \\
\hline ELV_STD & Standard deviation of terrain-unit mean elevation & -.105 \\
\hline SLO_ANG & Mean slope angle & -1.075 \\
\hline SLO_ANG2 & Mean slope angle squared & 1.068 \\
\hline ANG_STD & Standard deviation of slope angle & .254 \\
\hline SLOLLEN & Slope length & -.051 \\
\hline LEN_STD & Standard deviation of channel angle & -.071 \\
\hline CONV & Convex slope profile & .058 \\
\hline IRR & $\mathrm{II}^{\circ}$ index of terrain-unit micro-relief & -.030 \\
\hline
\end{tabular}

\begin{tabular}{lcc}
\hline (b) & & \\
\hline Actual groups & Predicted group membership & \\
\hline & Group 1 (stable slopes) & Group 2 (unstable slopes) \\
\hline Group 1 (stable slopes) & $69.1 \%$ & $30.9 \%$ \\
Group 2 (unstable slopes) & $17.1 \%$ & $82.9 \%$ \\
\hline
\end{tabular}

Terrain-units correctly classified: $78.0 \%$

istics of the failed masses (Varnes et al., 1984; Rib and Liang, 1978). The detail and precision of these maps is primarily dependent on the experience and skill of the investigator and secondly on the quality of the aerial photographs and base maps used.
As confirmed by the results of this investigation, geomorphologically-based landslide inventories are inherently affected by a relevant degree of uncertainty which leads to large or very large positional mismatches between maps produced by different research teams (Table 1, Figs. 2, 3 and 
Table 6. Comparison of the terrain-units classified as stable and unstable in the Staffora Basin by the discriminant models based on the Milan and Perugia landslide inventories

\begin{tabular}{ccc}
$\begin{array}{c}\text { Terrain units classified by the } \\
\text { model based on Milano } \\
\text { inventory as: }\end{array}$ & $\begin{array}{c}\text { Terrain units classified by the model based on } \\
\text { Perugia inventory as: }\end{array}$ & \\
& & Stable \\
Stable & $37.7 \%$ & Unstable \\
Unstable & $2.1 \%$ & $46.4 \%$ \\
\hline
\end{tabular}

Overall disagreement between models: $15.5 \%$

4). Paradoxically, when an area is independently mapped by different investigators, the unstable surface common to all inventories, which can hence be classified as certainly unsafe, progressively decreases to a value next to $0 \%$ as the number of the investigators increases (Table 1, Fig. 5).

Notwithstanding, when landslide deposits are aggregated into a morphologically-meaningful terrain-unit, such as the main slope-unit, map mismatch reduces to percentages in the range of 20-25, which are close to the errors that affect most of the measurements of data from the environment. This result confirms what can be observed by visually inspecting the three inventory maps of Figs. 2, 3 and 4: in many cases the same landslide deposit can be recognised in the three inventories where it appears with different boundaries and typological characteristics (see Fig. 6).

Therefore the agreement index used in this work, although formally correct, appears to be too conservative and "pessimistic" for comparing different inventory maps. Furthermore, the more relevant issue does not regard the ability of geomorphologists to identify and map landslide deposits, but how this information can be effectively used in setting forth constrains in land exploitation. In this context, inventory maps can be misleading when they are transferred to the local administrators who may assume that the landslide boundaries are certain, well-defined entities discriminating safe and unsafe land surface.

This assertion becomes crucial in urban area where the incorrect mapping of a landslide boundary may have dramatic economic and social implications (Figs. 6 and 7).

A better way to transfer information on land instability would be in the form of density maps based on slope-units where the limits between terrain units consist of easily discernible features such as stream-lines and divides. The drawback of the approach refers to the fact that the loss in spatial resolution is not compensated by other added value.

An effective alternative to density maps is provided by maps displaying the outcomes of multivariate models that predict landslide spatial occurrence. The results of the analyses showed that the two discriminant models are based on nearly the same set of predictors and have the same discriminant power (Tables 4 and 5). This demonstrates that, despite the positional differences of the two landslide inventories (i.e. the dependent variables), these models are very sim- ilar and relatively insensitive to landslide map discrepancies. Consequently, the comparison of terrain-units, classified as stable and unstable by the discriminant models applied to the landslide deposits of the Milano and Perugia inventories indicates that their degree of agreement is significantly better than that of the corresponding density maps $(15.5 \%$ vs. $21.2 \%$, Tables 3 and 5).

Lastly, statistical hazard models, by incorporating information from the geological, geomorphological and other environmental characteristics of the study area that control slope failure, well compensate the loss of spatial resolution with a mix of different information sources that is (or should be) less dependent on the skill of the landslide surveyors.

Acknowledgements. R. Pike, US Geological Survey - Menlo Park, critically read the manuscript providing valuable suggestions. The set of the environmental data for the Staffora Basin was developed and implemented as part of a major project aimed at assessing slope instability in sample areas of the Lombardia region. In particular, G. Crosta and S. Sterlacchini, University of Milan-Bicocca, Milan, produced one of the three landslide inventory maps and revised the existing geological map of the study area (CNR GNDCI publication number 2528).

\section{References}

Antonini, G., Ardizzone, F., Cardinali, M., Carrara, A., Detti, R., Galli, M., Guzzetti, F., Reichenbach, P., Sotera, M., and Tonelli, G.: Rapporto conclusivo: tecniche e metodologie idonee alla produzione di carte della pericolosità e del rischio da frana in aree campione rappresentative del territorio della regione Lombardia, unpublished report, 2000.

Brabb, E. E.: Innovative approaches to landslide hazard mapping. Proceed. IV Int. Symp. Landslides, Toronto, 1, 307-324, 1984.

Brabb, E. E., Pampeyan, E. H., and Bonilla, M. G.: Landslide susceptibility in San Mateo County, California, US Geological Survey Misc. Field Studies Map, MF360, scale 1:62 500, 1972.

Campbell, R. H.: Isopleth map of landslide deposits, Point Dume Quadrangle, Los Angeles Country, California. An experiment in generalizing and quantifying areal distribution of landslides, US Geological Survey Miscellaneous Field Studies Map, MF-535, scale 1:24000, 1973.

Carrara, A.: Drainage and divide networks derived from highfidelity digital terrain models, In: Quantitative analysis of mineral and energy resources, (Eds.) Chung, C. F., et al., NATO-ASI Series, 581-597, D. Reidel Pub. Co., Dordrecht, 1988. 
Carrara, A., Cardinali, M., Detti, R., Guzzetti, F., Pasqui, V., and Reichenbach, P.: GIS techniques and statistical models in evaluating landslide hazard, Earth Surface Processes and Landforms, 16, 5, 427-445, 1991.

Carrara, A., Cardinali, M., and Guzzetti, F.: Uncertainty in assessing landslide hazard and risk, ITC Jour., 2, 172-183, 1992.

Carrara, A., Cardinali, M., Guzzetti, F., and Reichenbach, P.: GIS technology in mapping landslide hazard, In: Geographical Information Systems in assessing Natural Hazards, (Eds) Carrara, A. and Guzzetti, F., Kluwer Pub., Dordrecht, The Netherlands, 135-175, 1995.

Carrara, A., Guzzetti, F., Cardinali, M., and Reichenbach, P.: Use of GIS technology in the prediction and monitoring of landslide hazard, Natural Hazard, 20, 117-135, 1999.

Cruden, D. M. and Varnes, D. J.: Landslides types and processes, In: "Landslide: investigation and mitigation", Transportation Research Board, Natural Academy of Science, 1994.

DeGraff, J. V.: Using isopleth maps of landslide deposits as a tool in timber scale planning, Bullettin American Association of Engineering Geologists, 22, 445-453, 1985.

Dikau, R., Brunsden, D., Schrott, L., and Ibsen, M. L.: Landslide recognition, identification, movements and causes, Chichester, UK, 251, 1996.

Guzzetti, F., Cardinali, M., Reichenbach, P., and Carrara, A.: Comparing Landslide maps: a case study in the upper Tiber river basin, Central Italy, Environmental Management, 25, 3, 247263, 2000.

Guzzetti, F., Carrara, A., Cardinali, M., and Reichenbach, P.: Landslide hazard evaluation: a review of current techniques and their application in a multi-scale study, Central Italy, Geomorphology, 31, 181-216, 1999.

Hansen, A.: Landslide hazard analysis, In: Slope Instability, (Eds.) Brunsden, D. and Prior, D. B., John Wiley and Sons, New York, 523-602, 1984.

Hutchinson, J. N.: Keynote paper: landslide hazard assessment, In: Landslides, (Ed.) Bell, Balkema, Rotterdam, 1805-1841, 1995.

Rib, H. T. and Liang, T.: Recognition and identification, In: Landslides analysis and control, (Eds.) Schuster, R. L., and Krizek, R. J., Washington Transportation research Board, Special Report 176, National Academy of Sciences, Washington, 34-80, 1978.

Van Westen, C. J.: Application of Geographic Information System to landslide hazard zonation ITC-Publication, 15, ITC, Enschede, 1993.

Varnes, D. J. and IAEG Commission on Landslides and Other Mass-Movements: Landslide hazard zonation: a review of principales and practice UNESCO Press, Paris, 1984.

Wright, R. H. and Nilsen, T. H.: Isopleth map of landslide deposits, southern San Francisco Bay Region, California, US Geological Survey Miscellaneous Field Studies Map, MF-550 (scale 1:250 000), 1974. 